\title{
Staged repair of severe open abdomens due to high-energy gunshot injuries with early vacuum pack and delayed tissue expansion and dual-sided meshes
}

\author{
Doğan Alhan, M.D., ${ }^{1}$ İsmail Şahin, M.D., ${ }^{2}$ Serbülent Güzey, M.D., ${ }^{3}$ Andaç Aykan, M.D., ${ }^{2}$ Fatih Zor, M.D., ${ }^{2}$ \\ Serdar Öztürk, M.D., ${ }^{2}$ Mustafa Nışancı, M.D., ${ }^{4}$ İsmail Hakkı Özerhan, M.D. ${ }^{5}$
}

\author{
1Department of Plastic, Reconstructive and Aesthetic Surgery, Eskisehir Military Hospital, Eskisehir \\ ${ }^{2}$ Department of Plastic, Reconstructive and Aesthetic Surgery, Gulhane Military Medical Academy, Ankara \\ ${ }^{3}$ Department of Plastic, Reconstructive and Aesthetic Surgery, Kasimpasa Military Hospital, Istanbul \\ ${ }^{4}$ Aesthetic Surgery Centre, Ankara \\ ${ }^{5}$ Department of General Surgery, Gulhane Military Medical Academy, Ankara
}

\begin{abstract}
BACKGROUND: Open abdomen is a salvage procedure that prevents catastrophes after severe intraabdominal traumas. However, following this life saving attempt, it is mostly not feasible to close the abdomen immediately after the recovery of intraabdominal injuries. Consequently, a staged reconstruction is required, and the first stage is usually a temporary closing approach. At the end of this stage, resulting giant "ventral hernia" is a burden for both the patient and the surgeon. Therefore a permanent repair is subsequently needed. Although there are many treatment modalities described for this goal, etiologies like high-energy gunshots may cause an exactly nuisance scene which can limit treatment options and reduce final success. Herein, it was the objective of this study to present our staged protocol to restore the abdominal wall defect and strategy for optimizing the results in such conundrum cases.
\end{abstract}

METHODS: Treatment was performed on nine male patients suffering from severe open abdomen due to high-energy gunshot injury. In all patients, temporary closure was provided by negative pressure wound treatment applied directly to the viscera and followed by skin grafting. Late permanent closure was performed with the lamination of expanded abdominal skin and dual-sided meshes.

RESULTS: The follow-up period ranged between 24 months to 4.5 years (mean, 3 years). During this period, no recurrence of ventral hernia, enteric fistula formation, abdominal infection and seroma formation was observed in any patient.

CONCLUSION: In this study, NPWT, tissue expansion and dual-sided mesh were used together as a staged procedure for optimizing the results in the clinical scenario of an open abdomen due to high-energy gunshot wound. Results were highly satisfactory for patients and acceptable aesthetically.

Key words: Dual meshes; gunshot injury; open abdomen; tissue expansion; vacuum assisted closure.

\section{INTRODUCTION}

Immediate closure of the abdominal wall after severe abdominal traumas is not always preferable because of the need for a

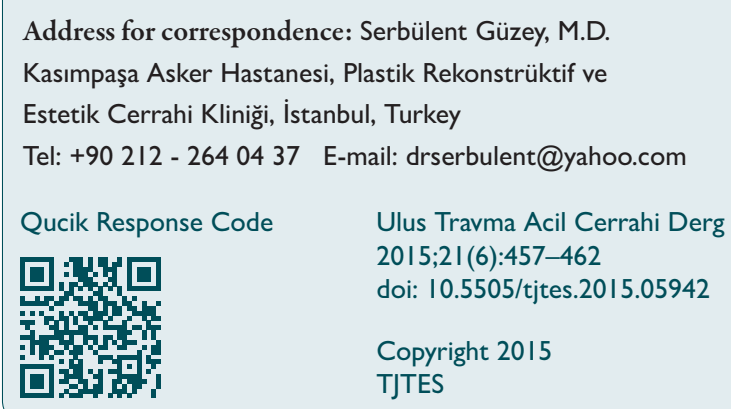

series of intra-abdominal interventions. At the end of this long treatment period, persistent intestinal edema and retraction of the abdominal wall are the main factors why fascias cannot be connected at an early time. Moreover, in severe abdominal traumas like the ones caused by high-energy gunshots, trauma may not only affect the intra-abdominal components but may also cause loss of domain of the abdominal wall.

A staged reconstruction protocol is required for this type of patients. Firstly, a temporary closing of the viscera is provided, and subsequently, permanent repair of the abdominal wall should be done. Many procedures have been advocated to close the viscera at the first stage. ${ }^{[1-6]}$ The fundamental principle in all of these procedures is forming the granulation tissue on the open abdominal wall and closing it with partial-thickness skin graft (PTSG). With these procedures, a 
defect called "planned ventral hernia" is formed in the front abdominal wall.

This abdominal hernia brings with itself numerous problems for the patient and the surgeon, and it is a necessity to repair the abdominal wall permanently in the future. Many methods including myofascial rotation flaps, distant flaps and tissue expansion have been advocated to repair this ventral hernia. [7-14] However, it cannot be expected to successfully close all kinds of defects byusing only one technique. The state of the components of the abdominal wall and the overall medical status of the patient are vitally important as well as the size of the defect for selecting the reconstructive technique. These situations obstruct the usage of local and distant flaps in highenergy gunshot injuries, which can lead to loss of domain and damage vascular pedicles of local reconstructive options. In this paper, a staged repair protocol of severe open abdomens in such scenario was presented. Temporary closing of the defect was provided with negative pressure wound treatment (NPWT), and late definitive surgery was performed with expanded abdominal skin due to dual-sided meshes.

\section{MATERIALS AND METHODS}

This study included nine male patients suffering from highenergy gunshot injures with open abdomen. Approved patient informed consent was taken from all patients. Mean age of the patients was 25 years (range, $21-30$ ). After completing intra-abdominal interventions, a temporary closing was provided at the beginning, and subsequently, a two-staged definitive reconstruction of the abdomen wall was performed.

\section{Surgical Protocol and Technique}

\section{Temporary Closing}

In order to obtain temporary closing on open visceral structures, negative-pressure wound treatment (NPWT) was directly performed on the visceral structures and no patch was used. After obtaining the granulation tissue, viscera were covered with a PTSG taken from the anterior thigh in accordance with the size of the defect.

\section{Definitive Reconstruction}

First stage (placement of tissue expander and tissue expansion): This stage was performed after the edema of the bowel was resolved. First, the areas tissue expanders would be placed were planned as the lateral of the skin graft preferably in the unscarred areas as much as possible. Following the small zigzag incision to the lateral of the skin graft, a pocket was prepared on the fascial plane using a lighted retractor. Proper tunnels were formed on the thoracic wall for a port. At the lateral abdominal area which is rich in perforator vessels, an attentive bleeding control was performed, and a drain was placed. After placing the tissue expander, 10\% inflation was applied in intraoperative scene.
On the $7^{\text {th }}$ postoperative day, tissue expanders were started to inflate. The inflation process was carried out by the same physician daily or every other day according to the examination of the expanding tissues.

\section{Second stage (permanent repair of the abdominal} wall): This stage was performed after the completion of the inflation process. Following the skin incision made from the lateral border of the graft tissue, the graft tissue was dissected out of the viscera. Since the skin grafts were very close to the intestinal serosa, dissection was performed meticulously in order to avoid micro perforation in the intestines. Later, the tissue expanders were removed, and capsulotomies were made parallel to the vertical axes in order to increase tissue advancement.

The composite (dual-sided) meshes (HI-TEX ${ }^{\circledR}$, textile Hi-Tec, France) were placed on the viscera in the manner of extending over the fascia $10 \mathrm{~cm}$ from the lateral sides and $5 \mathrm{~cm}$ from the top and bottom and fixed by 3 lines of single sutures (Fig. I). The sutures in the inner line were performed on the edges of the fascia against the possibility of intestinal herniation. By hastening the abdominal wall from both sides, the fascial edges were drawn nearer and the patch was sutured is such tense form. "Jackson Pratt" drains were placed on both sides of the abdominal wall, and then, the skin edges were brought together. Once making sure that the expanded skin was sufficient for full closing of the defect, the graft was completely excised and skin edges were sutured (Fig. 2).

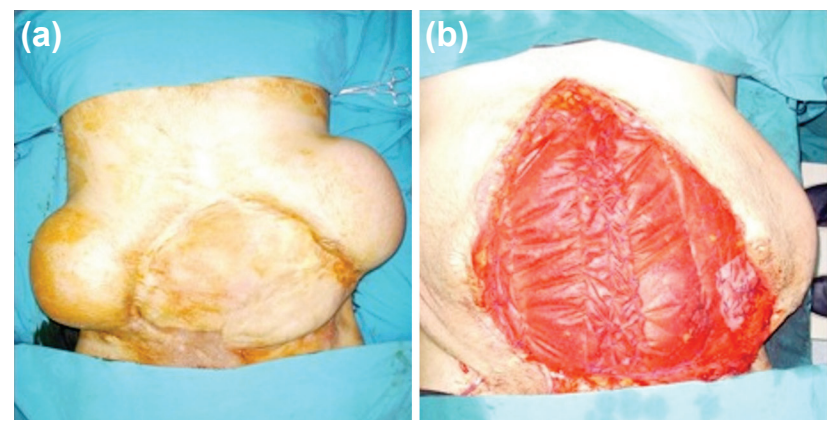

Figure 1. Case 1, (a) abdominal wall defect covered with matured skin graft and expanders were placed both sides. (b) Intra-operative view; composite meshes were placed on the viscera and fixed by single sutures.
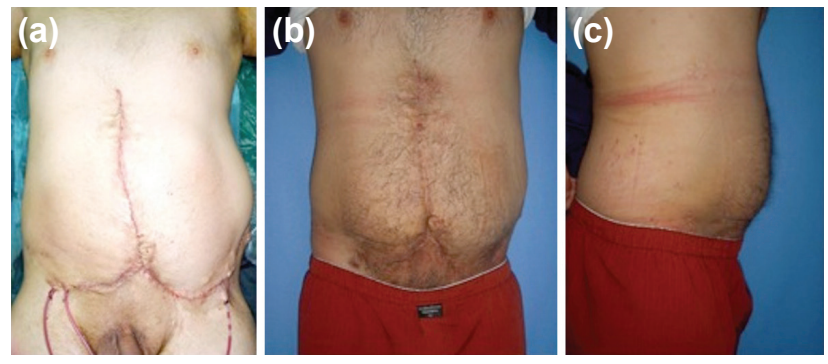

Figure 2. Same patient (case 1), after definitive restoration of abdominal wall. (a) Early appearance postoperatively. (b, c) Late views at postoperative $13^{\text {th }}$ month. 


\section{RESULTS}

NPWT was performed on average of five sessions; each session lasting for four days. It was observed in all patients that the skin grafts were entirely viable. An average of seven months (range, 6-II months) passed for the second phase after the forming of the maturation of the grafts, and during this time, the patients wore an abdominal corset. Mean horizontal width of the ventral hernia was $23 \mathrm{~cm}$ (range, 17-25 $\mathrm{cm}$ ) and mean vertical width was $25 \mathrm{~cm}$ (range, 22-30 cm). Two patients underwent a unilateral procedure with an 850 cc of rectangular tissue expander, and bilateral $700 \mathrm{cc}$ and 750 cc of rectangular tissue expanders were used on others and an average of $20 \%$ over-inflation was performed.

Infection developed in one of the patients with unilateral tissue expander, and this device was salvaged by antibiotherapy and rigorous irrigation that was performed twice a day. During the first and second phases of the treatment, no abdominal complications such as infection, formation of fistula, and intestinal obstruction were observed. Skin flaps were sutured without any tonicity, and no skin necrosis was observed on the flaps after the third stage. Only a superficial skin dehiscence in size of $2 \times 1 \mathrm{~cm}$ occurred in one patient. Conservative dressing and a stamp skin graft treated it seamlessly.

The follow-up of the patients ranged from 24 months to 4.5 years (mean, 3 years). During this period, no recurrence of ventral hernia, enteric fistula formation, abdominal infection and seroma formation occurred in any patient.

The patients were forced to use an abdominal corset for an average of 18 months (12-24 months) and were recommended to use it a lifetime while engaged in strenuous activities.

\section{Cases}

Case I- A 22-year-old male patient suffered high-energy gunshot injury. Intestine and colon resections and end-toend anastomoses were performed in the acute period. Upon theoccurrence of a necrotizing fasciitis, the abdomen was left open and the patient underwent a series of exploratory laparotomies and debridements. During this period, one third inferior part of the left rectus abdominis muscle with a wide overlying skin block were debrided and a horizontally skin defect was formed. The patient was consulted by our clinic on the 20th day after trauma. After five sessions of negative-pressure wound treatment, the defect was covered by PTSG. Six months later, a ventral hernia covered with matured skin graft in size of $25 \times 25 \mathrm{~cm}$ was observed, and the patient underwent the first stage of definitive reconstruction which $850 \mathrm{cc}$ tissue expanders placed on both sides of anterior abdominal wall (Fig. I). Tissue expansion was completed in forty days, and the abdominal wall was restored. No complication was seen for a period of 30 - months follow-up (Fig. 2).
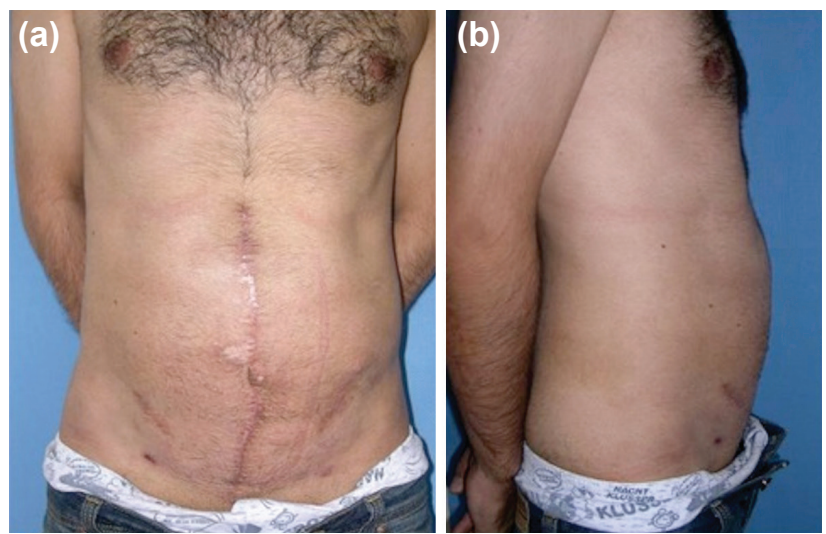

Figure 3. (Patient in case 2), Abdominal wall defect before definitive reconstruction; (a) covered with matured skin graft in size of $25 \times 25 \mathrm{~cm}$. (b) $750 \mathrm{cc}$ tissue expanders were placed both sides.
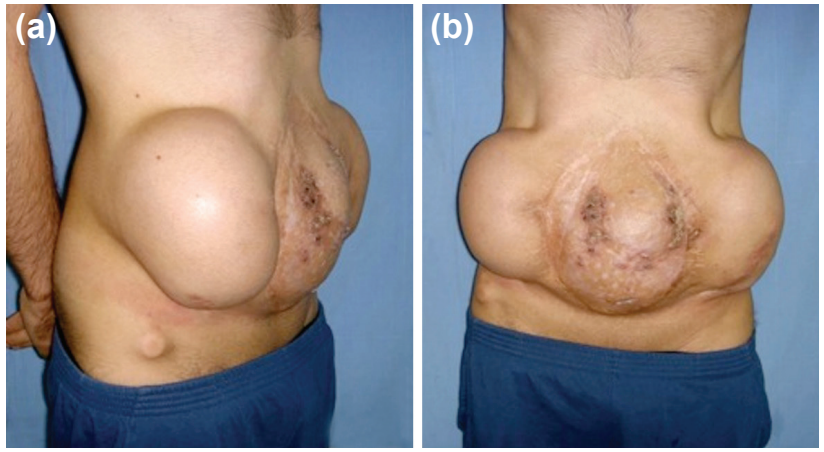

Figure 4. (a, b) Same patient (case 2), Late views at postoperative $12^{\text {th }}$ month.

Case 2- The patient was a 30 year-old malewho had suffered high-powered gunshot injury. Colon resection and colostomy (Hartmann procedure) were performed and the abdomen was left open. The patient was consulted on the $15^{\text {th }}$ day of injury. After performing eight sessions of negative-pressure wound treatment, the abdomen was closed by PTSG. Colostomy was restored nine months later, and $750 \mathrm{cc}$ tissue expanders were placed on both sides four months after colostomy restoration. During this period, the defect at the frontal abdominal wall was covered with PTSG in the size of $30 \times 25 \mathrm{~cm}$ (Fig. 3). Tissue expansion was completed in three months and abdominal wall restoration was performed. No problem was encountered with the patient at 2 years followup (Fig. 4).

\section{DISCUSSION}

Though leaving the abdomen open after traumas was put forward as a life saving procedure, it brings many other problems such as fluid and electrolyte imbalance, loss of protein, hemostasis and deterioration in temperature balance, dryness, damaging of the abdominal viscera and evisceration, formation of fistula, hemorrhage and infection. Therefore, after eliminating intra-abdominal damage and improving the overall status of the patient, the abdomen must be closed immedi- 

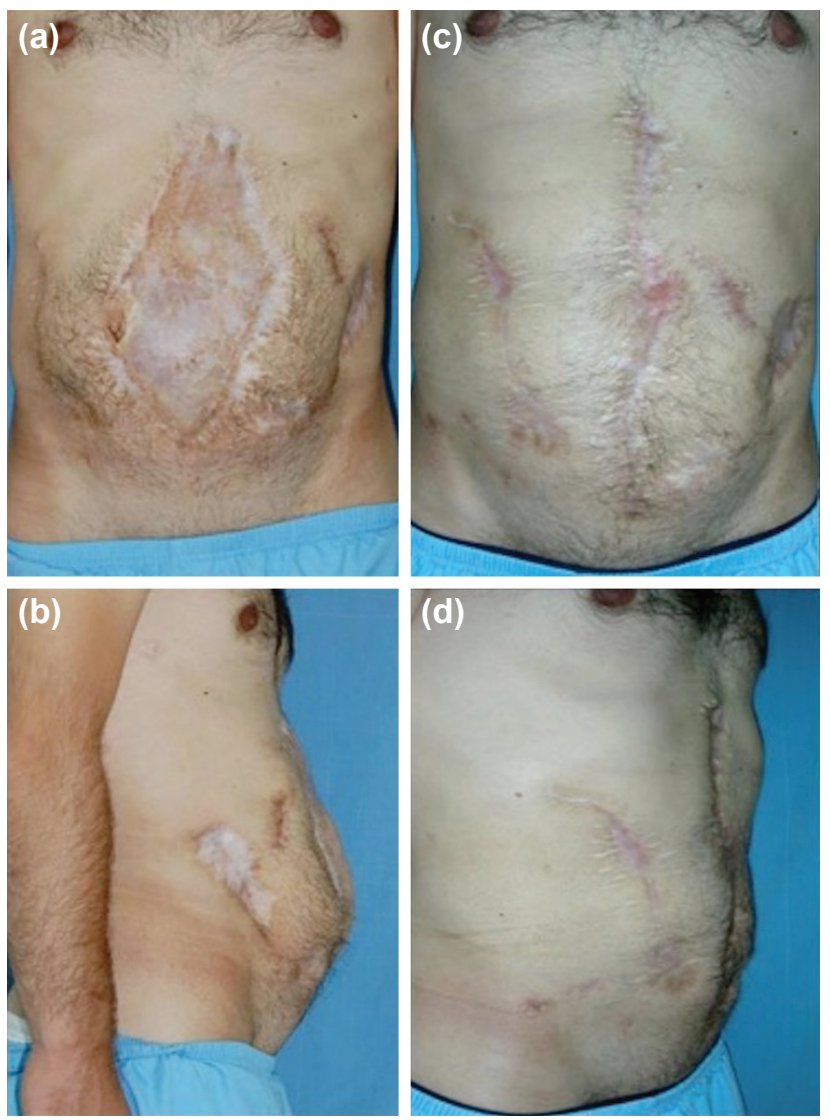

Figure 5. 22 years-old male patient. A $30 \times 15 \mathrm{~cm}$ defect was closed; (a, b) appearances before definitive surgery, (c, d) appearances nine months after permanent closure.

ately. However, it is not mostly possible to close the abdominal wall in anatomical layers. The main reasons are expanding abdominal content, lateral retraction of the abdominal muscles and loss of domain of abdominal wall mostly resulting after serious traumas like high-energy gunshot injuries. In addition, a major reconstructive surgery may not be applicable for multiple trauma patients as they have residual systemic diseases. Consequently, a staged reconstruction is required for this type of patients: first a temporary closing is provided, and subsequently, permanent repair should be done. ${ }^{[15,16]}$

The techniques for temporary closing of the abdomen aim to protect the viscera somehow. In this sense, absorbable or non-absorbable meshes, the Bogota Bag and negativepressure wound therapy are used. The main objective in all of these procedures is forming the granulation tissue on the open abdominal wall and closing it with partial-thickness skin graft.

NPWT, while acting by increasing the granulation tissue and the blood stream, reducing the edema and the bacterial count, has gained popularity due to these qualities in treating the complex and chronic wounds in the last 15 years. Using this method in open abdomens was inevitable and Barker and his colleagues used the technique called Vacuum Pack or
"Sandwich" in open abdomens in 2000. ${ }^{[17]}$ Negative pressure therapy advances over other methods with the advantages it provides. $^{[18]}$

In this study, NPWT was directly applied on the viscera for temporary closure and no mesh was used, and then, PTSG was placed on the formed granulation tissue. As mentioned in many previous studies, granulation layer is formed after the usage of the prosthesis mesh, and mesh extrusion and fistula formation are widely encountered complications. ${ }^{[1,20]}$ On the contrary, no fistula and infection formation was found in the temporary closure stage of our patients, which is a positive fact of our using NPWT directly on the viscera and not a mesh.

It is not a preferable method to close a full thickness abdominal wall defect permanently with a partial thickness skin. Partial skin grafting is prone to sinus and fistula formation and may not be sufficient to protect the internal organs against traumas. All these reasons make it a necessity to repair the abdominal wall with a permanent way in the future. For the late definitive restoration of the abdominal wall, many flaps that provide contractile muscle and fascial support have been advocated including rectus femoris, latissimus dorsi, tensor fascia latae and vastus lateralis myofascial flaps. ${ }^{[7-1 !]}$ However, due to the limited rotation arcs and/or small size of the flaps, these defects generally require more than one flap, which limits the usage of these flaps. On the other hand, both the scar and functional loss in donor site are other limiting factors. In 1990, Ramirez and his colleagues defined the technique they called as "components separation", which is based on relaxation incisions to the lateral of the rectus muscle allowing medial movement of the rectus muscle. ${ }^{[2]]}$ Although it was declared that wide defects of $20 \mathrm{~cm}$ could be closed with this technique, a high ratio of recurrent hernia, which was also noted, should not be overlooked. ${ }^{[22-24]}$ On the other hand, in traumas that damage the abdominal domain and the epigastric vessels, it's hard to use this reconstructive choice.

The usage of tissue expanders in abdominal wall reconstruction is not novel, butit does not also deserve to be archaic. We believe that it still has its validity, and in this study we used tissue expanders for late definitive reconstruction of serious abdominal wall defects caused by high-energy gunshot injuries. Byrd and Hobar pioneered thetissue expansion protocol in abdominal wall reconstruction in 1989. They placed expanders under anterior rectus sheet in two cases. ${ }^{[25]}$ In 2000 , they placed an expander between the internal oblique and transversus abdominis muscles in a traumatic abdominal wall defect. ${ }^{\left[{ }^{I I]}\right.}$ We placed expanders in subcutaneous plane as used previously in the reconstruction of abdominal wall defects. ${ }^{[2-14]}$ As distinct from previous studies in our proto$\mathrm{col}$, an enduring abdominal wall was acquired by lamination of the expanded abdominal skin and subcutaneous tissue and composite mesh together.

The usage of meshes in the treatment of abdominal hernia 
is a very common method. Approximately a decade ago, the usage of non-absorbable (polypropylene) meshes in maintaining the entirety of the abdominal wall was the most popular method. Although the ability of holding the visceral content inside the peritoneum is fairly good for this kind of meshes, serious fistula ratio has been reported due to the adhesive and erosive effects of the material on the intestines. However, it has been advocated in several studies that the usage of absorbable meshes reduce the likelihood of this problem. We used dual meshes for our patients in the last stage of our protocol. The side of the mesh that touches the viscera is in a polytetrafluoroethylene structure with unbraided smooth surface, and the outer side is in polypropylene structure. The adhesive and erosive effect on the visceral organs is minimalized thanks to its special structure and it aims to have a longlasting endurance. We believe that the mesh we used had its contribution to our success.

After the process of tissue expansion, a capsula formation was formed. While the capsula is an unwanted structure in many other parts of the body since it forms thickness and reduces the elasticity of the flap, this feature creates a serious advantage in our treatment of abdominal defects. An excellently vascularized autogenetic tissue advancing onto the prosthetic mesh used in permanent repair was beneficial in reducing complications that would occur due to the mesh. In addition, no seroma formation was seen in our series. We believe the main reasons of this result were the capsulotomies and long-term use of drains. Drains were removed at an average of two weeks after the reconstruction.

The method was simple and the results were satisfactory. Donor site morbidities were not seen when other flap techniques were considered. The contracted skin was restored in its native location by expanding, and in this sense, a treatment with color and tissue match was realized. Another and most important advantage of this technique is that it can be used in any kind of etiologic-reasoned abdominal wall defect. All patients treated in this study were patients injured by high-energy gunshots. An extremely successful result was achieved even from a patient with rectus abdominis muscle defect and a skin defect in the horizontal plan (Fig. 5). It is nearly impossible to close these kinds of defects with the usage of local myofascial flap. Moreover, it would be a great luck if the entirety of the vascular structures that were exposed to the "blast effect" were preserved. The disadvantages of the procedure are that the process is slow and that it requires a long-term hospitalization period. It was in our favor that our patients were young.

In conclusion, we aimed to present a modern and safe alternative treatment approach for staged repair of severe open abdomens. In previous studies, each of these treatment modalities was used individually for different clinical scenarios. In this study, NPWT, tissue expansion and dual-sided mesh were used together as a staged procedure for optimizing the results in the clinical scenario of an open abdomen due to high-energy gunshot wound. We also optimized the usage of each technique according to review of the literature.

\section{Acknowledgement}

The Authors have no conflict of interest any financial and personal relationships with other people or organizations that could inappropriately influence (bias) their work. Examples of potential conflicts of interest include employment, consultancies, stock ownership, honoraria, paid expert testimony, patent applications/registrations, and grants or other funding.

Conflict of interest: None declared.

\section{REFERENCES}

1. Howdieshell TR, Yeh KA, Hawkins ML, Cué JI. Temporary abdominal wall closure in trauma patients: indications, technique, and results. World J Surg 1995;19:154-8. CrossRef

2. Stonerock CE, Bynoe RP, Yost MJ, Nottingham JM. Use of a vacuumassisted device to facilitate abdominal closure. Am Surg 2003;69:1030-5.

3. Wechselberger G, Schoeller T, Rainer C, Papp C. Temporary closure of full-thickness abdominal-wall defects with mesh grafts. Langenbecks Arch Surg 1999;384:88-9. CrossRef

4. Greene MA, Mullins RJ, Malangoni MA, Feliciano PD, Richardson JD, Polk HC Jr. Laparotomy wound closure with absorbable polyglycolic acid mesh. Surg Gynecol Obstet 1993;176:213-8.

5. Voyles CR, Richardson JD, Bland KI, Tobin GR, Flint LM, Polk HC Jr. Emergency abdominal wall reconstruction with polypropylene mesh: short-term benefits versus long-term complications. Ann Surg 1981;194:219-23. CrossRef

6. Gervin AS, Fischer RP. The reconstruction of defects of the abdominal wall with split thickness skin grafts. Surg Gynecol Obstet 1982;155:4124.

7. Houston GC, Drew GS, Vazquez B, Given KS. The extended latissimus dorsi flap in repair of anterior abdominal wall defects. Plast Reconstr Surg 1988;81:917-24. CrossRef

8. Ramasastry SS, Tucker JB, Swartz WM, Hurwitz DJ. The internal oblique muscle flap: an anatomic and clinical study. Plast Reconstr Surg 1984;73:721-33. CrossRef

9. Ger R, Duboys E. The prevention and repair of large abdominal-wall defects by muscle transposition: a preliminary communication. Plast Reconstr Surg 1983;72:170-8. CrossRef

10. Williams JK, Carlson GW, deChalain T, Howell R, Coleman JJ. Role of tensor fasciae latae in abdominal wall reconstruction. Plast Reconstr Surg 1998;101:713-8. CrossRef

11. Rohrich RJ, Lowe JB, Hackney FL, Bowman JL, Hobar PC. An algorithm for abdominal wall reconstruction. Plast Reconstr Surg 2000;105:20217. CrossRef

12. Paletta CE, Huang DB, Dehghan K, Kelly C. The use of tissue expanders in staged abdominal wall reconstruction. Ann Plast Surg 1999;42:25965. CrossRef

13. Carlson GW, Elwood E, Losken A, Galloway JR. The role of tissue expansion in abdominal wall reconstruction. Ann Plast Surg 2000;44:14753. CrossRef

14. Livingston DH, Sharma PK, Glantz AI. Tissue expanders for abdominal wall reconstruction following severe trauma: technical note and case reports. J Trauma 1992;32:82-6. CrossRef 
15. Jernigan TW, Fabian TC, Croce MA, Moore N, Pritchard FE, Minard G, et al. Staged management of giant abdominal wall defects: acute and long-term results. Ann Surg 2003;238:349-57. CrossRef

16. Baker S, Millard DR Jr. Two-stage abdominal-wall reconstruction of sepsis-induced dehiscence. Plast Reconstr Surg 1995;96:898-904. CrossRef

17. Barker DE, Kaufman HJ, Smith LA, Ciraulo DL, Richart CL, Burns RP. Vacuum pack technique of temporary abdominal closure: a 7-year experience with 112 patients. J Trauma 2000;48:201-7. CrossRef

18. Miller PR, Meredith JW, Johnson JC, Chang MC. Prospective evaluation of vacuum-assisted fascial closure after open abdomen: planned ventral hernia rate is substantially reduced. Ann Surg 2004;239:608-16. CrossRef

19. Fansler RF, Taheri P, Cullinane C, Sabates B, Flint LM. Polypropylene mesh closure of the complicated abdominal wound. Am J Surg 1995; 170:15-8. CrossRef

20. Karakousis CP, Volpe C, Tanski J, Colby ED, Winston J, Driscoll DL. Use of a mesh for musculoaponeurotic defects of the abdominal wall in cancer surgery and the risk of bowel fistulas. J Am Coll Surg 1995;181:11-6.

21. Ramirez OM, Ruas E, Dellon AL. "Components separation" method for closure of abdominal-wall defects: an anatomic and clinical study. Plast Reconstr Surg 1990;86:519-26. CrossRef

22. de Vries Reilingh TS, van Goor H, Charbon JA, Rosman C, Hesselink EJ, van der Wilt GJ, et al. Repair of giant midline abdominal wall hernias: "components separation technique" versus prosthetic repair : interim analysis of a randomized controlled trial. World J Surg 2007;31:756-63.

23. Lowe JB 3rd, Lowe JB, Baty JD, Garza JR. Risks associated with "components separation" for closure of complex abdominal wall defects. Plast Reconstr Surg 2003;111:1276-88. CrossRef

24. Fabian TC, Croce MA, Pritchard FE, Minard G, Hickerson WL, Howell $\mathrm{RL}$, et al. Planned ventral hernia. Staged management for acute abdominal wall defects. Ann Surg 1994;219:643-53. CrossRef

25. Byrd HS, Hobar PC. Abdominal wall expansion in congenital defects. Plast Reconstr Surg 1989;84:347-52. CrossRef

\section{ORİJINAL ÇALIŞMA - ÖZET}

\section{Yüksek enerjili ateşli silah yaralanmalarına bağlı açık karın olgularının tedavisinde erken dönem vakum uygulaması ile geç dönem doku genişletme ve çift taraflı yama \\ Dr. Doğan Alhan, ${ }^{1}$ Dr. İsmail Şahin, ${ }^{2}$ Dr. Serbülent Güzey, ${ }^{3}$ Dr. Andaç Aykan, ${ }^{2}$ Dr. Fatih Zor, ${ }^{2}$ \\ Dr. Serdar Öztürk, ${ }^{2}$ Dr. Mustafa Nışancı, ${ }^{4}$ Dr. İsmail Hakkı Özerhan ${ }^{5}$}

${ }^{1}$ Eskişehir Asker Hastanesi, Plastik Rekonstrüktif ve Estetik Cerrahi Kliniği, Eskişehir

${ }^{2}$ Gülhane Askeri Tıp Akademisi, Plastik Rekonstrüktif ve Estetik Cerrahi Anabilim Dalı, Ankara

${ }^{3}$ Kasımpaşa Asker Hastanesi, Plastik Rekonstrüktif ve Estetik Cerrahi Kliniği, İstanbul

${ }^{4}$ Estetik Cerrahi Merkezi, Ankara

${ }^{5}$ Gülhane Askeri Tıp Akademisi, Genel Cerrahi Anabilim Dalı, Ankara

AMAÇ: Açıı karın; ciddi abdominal travmalar sonrası ortaya çıkabilecek katastrofilerden kaçınılması amacıyla uygulanan bir koruyucu prosedürdür. Fakat, açık karın olgularında yaralanma sonrası abdominal iyileşme sağlansa bile erken dönemde defekt alanının kapatılması çok kolay olmamaktadır. Bu nedenle açık karın olgularının tedavisinde aşamalı onarım ihtiyacı bulunurken, birinci aşama geçici kapamadır. Bu aşamanın sonrasında ortaya çıkan dev boyutlu ventral herni ise hem cerrah hem de hasta açısından büyük sıkıntı oluşturmaktadır. Oluşan bu tablo nedeniyle kalıı bir onarım kaçınımazdır. Her ne kadar bu amaçla birçok farklı tedavi yaklaşımları tanımlanmış olsa da ateşli silah yaralanması gibi yüksek enerjili travmalar nihai sonucu etkileyebilen, tedavi seçeneklerini kısıtlayan karmaşık tabloların oluşumuna neden olabilir. Bu çalışmada abdominal duvar defekti bulunan komplike olguların onarımında uyguladığımız aşamalı tedavi yaklaşımı sunuldu.

GEREÇ VE YÖNTEM: Ateşli silah yaralanmasına bağı açık karın bulunan dokuz erkek hastada aşamalı tedavi uygulandı. Bütün hastalarda geçici kapatma direkt visera üzerine yerleştirilen negatif basınçlı yara bakım uygulaması ve sonrasında gerçekleştirilen cilt grefti yardımıyla sağlandı. Geç dönemdeki kalııı onarım ise ekspanse edilen abdominal duvarın laminasyonu ve iki taraflı yama sayesinde gerçekleştirildi.

BULGULAR: Hastaların takip süreleri 24 ay ile 4.5 yıl arasında (ortalama üç yıl) değişmekteydi. Bu periyot dahilinde hiçbir hastada ventral hernide nüks, enterik fistül, abdominal enfeksiyon ve seroma oluşumu gözlenmedi.

TARTIŞMA: Bu çalışmada yüksek enerjili ateşli silah yaralanmalarına bağlı açık karın olgularının tedavisinde negatif basınçlı yara terapisi, doku genişletici ve çift taraflı yama uygulamaları aşamalı olarak kullanılmışıı. Sonuçlar hastalar açısından son derece memnuniyet verici olup estetik sonuçlar ise kabul edilebilir düzeydedir.

Anahtar sözcükler: Açık karın; ateşli silah yaralanması; çift taraflı mesh; doku genişletici; vakum yardımlı kapatma.

Ulus Travma Acil Cerrahi Derg 2015;2I(6):457-462 doi: 10.5505/tjtes.2015.05942 